\title{
作付け前のマメシンクイガ（チョウ目：ハマキガ科）被害リスク推定に 基づく防除対策の選定
}

\author{
竹内 博昭 ${ }^{1, *} \cdot$ 石本 万寿広 ${ }^{2} \cdot$ 阿算 和基 $^{3} \cdot$ 岩田 大介 $^{2}$ \\ 栗原 潤 $^{3, \dagger} \cdot$ 遠藤 信幸 $^{1} \cdot$ 渋谷 和樹 $^{1}$ \\ ${ }^{1}$ 農業・食品産業技術総合研究機構中央農業研究センター \\ 2 新潟県農業総合研究所作物研究センター \\ ${ }^{3}$ 長野県農業試験場
}

Pre-planting Estimation of Damage Risk and Selection of Control Methods for the Soybean Pod Borer, Leguminivora glycinivorella (Lepidoptera: Tortricidae). Hiroaki Takeuchi, ${ }^{1, *}$ Masuhiro Ishimoto, ${ }^{2}$ Kazuki Aso, ${ }^{3}$ Daisuke Iwata, ${ }^{2}$ Jun Kurihara, ${ }^{3, \dagger}$ Nobuyuki Endo ${ }^{1}$ and Kazuki Shibuya ${ }^{1}{ }^{1}$ Hokuriku Plant Protection Group, Central Region Agricultural Research Center, NARO; 1-2-1 Inada, Joetsu, Niigata 943-0193, Japan. ${ }^{2}$ Niigata Agricultural Research Institute, Crop Research Center; Nagakura 857, Nagaoka, Niigata 940-0826, Japan. ${ }^{3}$ Nagano Agricultural Experiment Station; Suzaka, Nagano 382-0051, Japan. Jpn. J. Appl. Entomol. Zool. 64: 115-124 (2020)

\begin{abstract}
To estimate the damage risk and select control methods for the soybean pod borer, Leguminivora glycinivorella (Matsumura) (Lepidoptera: Tortricidae), over 200 soybean fields cultivated by farmers and treated with insecticides 0-2 times for the borer were surveyed in Niigata and Nagano Prefectures from 2015 to 2018. A decision tree analysis was performed on the non-treated data. The tree-model had four terminal nodes and was split by three factors: soybean continuous cropping year, damage rate in the previous year, and distance to the nearest field where soybeans were cropped in the previous year. The four terminal nodes were ordered from low to high according to the damage level of the fields classified to each node. The order of nodes did not differ between the modeling data and test data, which were data from other uncontrolled fields. As the number of insecticide treatments increased, the ratio of low-damage-level fields increased to $>90 \%$ in all terminal nodes except the highest-damage-level node. These results indicate that the order of the four terminal nodes may represent the order of damage risk. The tree-model may enable rational selection of the number of insecticide treatments or rotation of soybean to rice before planting.
\end{abstract}

Key words: Damage risk; decision-tree; rotation; soybean pod borer; integrated pest management

\begin{abstract}
緒
言

マメシンクイガ Leguminivora glycinivorella (Matsumura) は，ハマキガ科 Tortricidae に属すダイズ Glycine max (L.)
\end{abstract} Merr. の害虫である（松村，1898）。幼虫は莢の中で子実を 食害して被害粒を発生させる。本州以北の比較的冷涼な地 域では年 1 化の発生であるが，被害粒率が数十\%を越える こともあり，防除対策が必要な害虫となっている（内藤・ 正木, 1962; Kobayashi and Oku, 1980; 石本 ·岩田, 2018). 本種に対する主要な防除対策は，輪作（ダイズからイネ
へ）と殺虫剤の使用である，このうち，水稲との輪作は， 水田作のダイズが増えた 1970 年代ごろから推奨されてい る. ダイズ後に水稲作をすると土中に生息する幼虫は水没 後短期間で死滅するとされる(竹内, 2018). しかし，水 稲作後のダイズであっても围場外から成虫が移入して被害 が生じる場合はある(小野, 2009; 石本・岩田, 2018)。一 方, 殺虫浻の使用も古くから研究され（Kuwayama, 1928), 現在では多くの種類の殺虫牏が使われている（久保田・横 田，2015). 散布回数は通常は 1 回であるが，多発生の場 合には2 回散布が必要とされている（木村・石谷, 2009;

\footnotetext{
*E-mail: thiroaki@affrc.go.jp

†現在長野県農業技術課

${ }^{\dagger}$ Present address: Agricultural Experiment and Extension Division, Nagano Prefectural Government, 692-2 Habashita, Minami Nagano, Nagano 380-8570, Japan.

2019 年 5 月 27 日受領 (Received 27 May 2019)

2020 年 5 月 12 日登載決定 (Accepted 12 May 2020)

DOI: $10.1303 /$ jjaez.2020.115
} 
久保田・横田, 2015; 對馬ら, 2017)。総合的害虫管理の概 念には複数の防除法を合理的に統合することが含まれてい る(中筋, 2008)。本種についても被害予測に基づいて多 様な防除対策を合理的に選択する方法が必要である.

害虫の被害を予測する方法には，原因となる害虫の発生 量を直接調査して予測する方法と気象条件や栽培条件など 間接的な情報で予測する方法とがあり，それでれ長所と短 所がある，本種の場合，発生量を直接調査して予測に用い る方法 (例えば，加進ら，2010）は，加害前世代の発生時 期や量を直接把握することと，調査から被害発生までの期 間が短いことから予測精度を高められる可能性がある。し かし, 予測から防除実施までの期間が短く, 柔軟な対応が 必要となる．また，対策の選択肢に輪作を入れることがで きない，一方，間接的な情報で予測する方法 (例えば，小 林・奥，1976）は，被害発生までの期間が長いので上述の 方法より精度は低い。しかし, 長い準備時間がとれ防除計 画は立てやすい，作付け前予測の場合は対策の選択肢に輪 作を入れることもできる，従って，それぞれの方法の長所 を生かした相補的な予測が望ましいと考えられる.

これまで本種を対象に，間接的な情報で被害を予測しよ うとした研究がいくつかある。例えば，気温と降水量に よる予測（高野，1985）や気温，降水量，地域の前年被害 粒率による予測 (平井, 1986) が研究されている. ただし, これらはいずれも広域的な被害の予測を目的としている. 本種の発生量は，固場間で大きなばらつきがあることから (船迫ら, 1977; 小野, 2009), 被害予測と対策の選択は個 別の圃場ごとに行うのが望ましい．

個別の圃場ごとの被害予測と対策の選択には，実施者の 負担が小さい簡易な方法が必要である. Yes/Noで分岐し ていくチャートで対策を選ぶ方法は, 選択手順が可視化さ れているので分かりやすく，分岐する要素を概観したり試 行的に選択したりできることから，取り組みやすい方法と 考えられる。これまでも本種の薬剤散布開始時期の決定手 順 (小野寺, 2012) や，本種を含むダイズの主要病害虫に 対する IPM 体系 (小野ら，2011）の提示の際に使われてい る.これらでは解析して得られた結果を統合してチャート が作られていることが多いが，別方法として，解析の際に チャートを直接作成するモデルを使うことも有効と考えら れる.

決定木は，非線形モデルの1つであり，上述の Yes/No などで分岐していくチャートを作成可能なモデルである (廣野・林, 2008)。要因間の相互関係を図示でき, Yes/No チャートと同様に結果を解釈しやすいという利点がある. 決定木は，以前から害虫管理の道具の 1 つと位置付けられ て抢り (Mumford and Norton, 1984; Dent, 2000)，チョウ目 やエビ目などの防除対策の選定法に活用された例がある (Valentine et al., 1976; Dumbauld et al., 2006; Woodill et al.,
2017）。 マメシンクイガに対してもこの方法を活用できる 可能性があると考えられる.

そこで本研究では，作付け前に被害リスクを推定して対 策を選定する方法の構築を目的として，できるだけ数多く の生産者圃場に打いて，栽培履歴，圃場周辺環境，本種発 生量，被害粒率などを調査した。得られた圃場データは防 除回数 $(0,1,2$ 回) で3つに分けた. そして, 播種前に入 手可能な情報の中から被害粒率に影響を及ぼす要因を特定 するために, 0 回防除戋場データを用いて被害程度を区分 する決定木を作成した，この決定木の検証は，別の 0 回防 除圃場データを用いて行った。 さらに, 1 回防除と 2 回防 除の効果を評価するために，この決定木で 1, 2 回防除围場 データを分類した後，区分ごと，防除回数ごとに被害程度 を比較した。そして，各区分の戋場に適した防除対策を推 定した。

な打, 本研究の一部は農林水産省の委託プロジェクト研 究「多収阻害要因の診断法打よび対策技術の開発」の予算 を用いて行われた。

\section{材料打よび方法}

\section{1. 調查圃場の選定}

できるだけ数多くの生産者戋場の栽培履歴やダイズ被 害粒率を把握することを目標に, 2015〜2018 年に新潟県 内 (上越, 中越地方) と長野県内 (北信, 中信, 南信地方) の 14 地区で，のべ 148 か所の生産者戋場を選定して調査 した，各地区は，新潟県では標高 $100 \mathrm{~m}$ 以下，長野県では 同 300〜 750m の範囲にあった。 また，調査围場の選定に あたっては，連作年数ができるだけ多様になるように考慮 した。これは，連作すると本種の発生量や被害が増加する (小野ら, 2011; 石本・岩田, 2018) とされているからであ る.のべ 148 か所のうち, 84 か所は 1 年の及調査したが, 29,22, 13 か所は順に 2, 3, 4 年続けて調査した. 調査年が 変わると栽培方法や環境条件が変わることが多いことと前 作の情報がある圈場の準備が難しいことから，本研究の解 析では同一圃場であっても各年のダイズ栽培は独立とみな した，そのため調查围場数は，のべ 260 戋場となった.

\section{2. 調査圃場の栽培方法}

調查圃場の栽培方針は生産者が決め, 生産者が実施し た。詳細な方法や履歴などは現地調査と事後の聞き取りや アンケートで把握した。それらの概要は次のようであっ た。面積の範囲は 5.5 $150 \mathrm{a}$ (中央值は $30 \mathrm{a}$ ) であった。栽 培品種は，エンレイ $(41 \%)$, タチナガ八 $(18 \%)$, ナカセ ンナリ $(18 \%)$ ，すずほまれ $(9 \%)$ ，里のほほえみ $(8 \%)$, ギンレイ $(5 \%)$ などのべ 8 品種であった。播種方法は狭畦 栽培もあったが，一般的な平暔と喃立て栽培が主だった。 播種日は，5月下旬から 7 月中旬まで幅があったが 6 月第 1 半旬が全体の $32 \%$ を占め最も頻度が高かった. 
調査した戋場では種子処理剂から散布剤まで多様な時期 に多様な殺虫剤が施用された。 8 月以降に散布された殺虫 剂に含まれていた有効成分は MEP, ダイアジノン, エト フェンプロックス，ペルメトリン，クロラントラニリプ ロールであった。既報（石本・岩田，2018）と同様に，8月 第 4 半旬以前の散布は本種への被害軽減効果が低いとみな して考慮しないこととした. 8 月第 5 半旬以降の散布回数 から，全圃場を 0 回，1回，2回防除戋場に分けた。順に 56, 157, 29 固場となった。 なお，被害粒率や防除内容が欠 測の 18 固場はこれらから除外した.

\section{3. 被害粒率の調査}

収穫期に各圃場でダイズ 25 茎を刈り取り，乾燥させ， 萊を開いて，かじられたような食害痕があるダイズ粒を選 別した. 粒数を計測した後, 被害粒率 (食害粒数調査全粒 数）を求めた。被害粒率は解析のために低，中，高の 3 段 階の被害程度に分けた（低：<5\%，中： ミ5\%かつ $<15 \%$, 高: $\geqq 15 \%$ と定義).この 3 段階としたのは, 同じダイズ 害虫の被害許容水準が, ウコンノメイガ Pleuroptya ruralis (Scopoli) では減収率 5.7\%（高橋ら，2011），ダイズカメム シ類では健全粒率 90 または $85 \%$ （伊藤ら，2006）とされて いるからである。

\section{4. シロイチモジマダラメイガの発生が多い圃場の抽出 と除外}

両県では，シロイチモジマダラメイガ Etiella zinckenella （Treitschke）の発生が多い固場がある可能性があった。 そ のような圃場を解析から除外するために, 2015〜2017 年 8〜10月に各地区の少なくとも 1 固場に打いて，フェロモ ントラップを用いてシロイチモジマダラメイガとマメシン クイガの発生量を並行して調査した. フェロモントラップ の設置方法は既報 (石本・岩田, 2018) と同様とし, マメ シンクイガのフェロモンルアーは, 市販品（信越化学株式 会社，東京）(樋口・望月，2011）を，シロイチモジマダラ
メイガのフェロモン（Tabata et al., 2008）を含むルアーは試 作品（信越化学株式会社, 東京) を用いた. のべ 182 圑場 を調査したところ, シロイチモジマダラメイガの捕獲数が マメシンクイガの捕獲数より多かったのは 5 固場のみであ り，マメシンクイガが優占していることが分かった。この 結果と労力の制約を考慮して, 2018 年はシロイチモジマダ ラメイガの発生量は調査しなかった.

また, 2015〜2017年の2年間は, 9 月下旬 (子実肥大後期) に各地区で 1 または 2 か所の戋場を選び, 10 茎を刈り取り, 萊を開いてシロイチモジマダラメイガなどマメシンクイガ 以外の種の幼虫の有無を調査したが, 他種はほとんど発見 されなかった.

これらを踏まえ, 被害程度が低の围場ではシロイチモジ マダラメイガの影響を考慮せず解析した。 被害程度が中ま たは高の戋場では, トラップによるシロイチモジマダラメ イガ捕獲数が，マメシンクイガ捕獲数の 11〜 24\%に達し

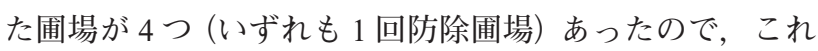
らは除外して解析した。このため 1 回防除圃場は 153 固場 となった.

\section{5. 決定木モデルのあてはめ}

生産者圃場では, 0 回防除圃場は 56 固場と少なかったの で，全てを決定木モデルの作成に用いた。 モデルの目的変 数は，上述した 3 段階の被害程度 (低, 中, 高) とした.

説明変数は，播種前に把握できる情報の中から9個を選 定した (Table 1). 各調査圃場の特徴を表す 6 変数 (Table 1 の番号順に調查年, 県, 地区, 圃場面積, 品種, 播種日) および, 被害予測ができる可能性がある 3 変数 (番号順に, 連作年数，前年の被害粒率，前年ダイズ圃場までの直線 距離) である. 変数の選定にあたっては，過去の多変量的 な解析の報告や被害と関連がある要因を考察している報告 (奥, 1993; 小野ら, 2011; 石本・岩田, 2018) を参考にし た.

Table 1. Explanatory variables and objective variable for analysis

\begin{tabular}{|c|c|c|c|}
\hline No. & Variable & Type of variable & Description \\
\hline 1 & Year & Nominal & 2015, 2016, 2017 and 2018. \\
\hline 2 & Prefecture & Nominal & Niigata or Nagano Prefecture. \\
\hline 3 & Name of local area & Nominal & Name of researched local area in the two prefectures. \\
\hline 4 & Field area & Continuous & Unit is square meters. \\
\hline 5 & Cultivar of soybean & Nominal & Enrei, Nakasennari, Tachinagaha, etc. \\
\hline 6 & Sowing date & Ordinal & $\begin{array}{l}\text { Sowing date is described as an ordinal period in which the period } \\
\text { from May } 20 \text { to July } 10 \text { is divided into } 10 \text { - or } 11 \text {-day intervals. }\end{array}$ \\
\hline 7 & Number of soybean continuous cropping years & Ordinal & $1,2,3$, or 4 or more. \\
\hline 8 & Damage rate in the previous year & Continuous & $0 \%$ when other plants were cropped there in the previous year. \\
\hline 9 & $\begin{array}{l}\text { Distance to nearest source field where soybeans } \\
\text { were cropped in the previous year }\end{array}$ & Continuous & $\begin{array}{l}\text { In the range of } 0-200 \mathrm{~m} \text { (distances }>200 \mathrm{~m} \text { were cut off) } \\
0 \mathrm{~m} \text { when soybeans were cropped continuously in the field. }\end{array}$ \\
\hline 1 & Damage level & Ordinal & $\begin{array}{l}\text { Low damage: }<5 \% \text {, Moderate damage: } \geq 5 \% \text {, and }<15 \% \text {, } \\
\text { High damage: } \geq 15 \% \text {. }\end{array}$ \\
\hline
\end{tabular}


選定した説明変数のうち，播種日（No. 6）は，5月下旬 から旬ごとに1〜6の番号をつけて順序変数とした．播種 期が 2 旬にまたがる場合は中間の值とした（例えば 1.5$)$. 連作年数（No. 7) は，作付け初年を 1 年とし， 4 年を越え る值は切り捨てとした。前年の被害粒率 (No. 8) は，ダイ ズ以外の作物が前年に栽培されていた場合は $0 \%$ とした。 前年ダイズ圃場までの直線距離（No. 9) は，前年にダイズ が栽培され当年に水田化されていない直近の娄場から調査 围場までの直線距離とした。調査围場の前作がダイズの場 合は $0 \mathrm{~m}$ とした. $200 \mathrm{~m}$ を越える距離は切り捨てとした。 なお，調査したダイズ围場周辺の当年や過去の状況などは 現地調査や聞き取りで確認したが，距離や面積の計測が必 要な場合には，地理院地図 (http://www.gsi.go.jp/) の計測 ッールを用いて数值を得た.

決定木分析の方法は複数あるが (廣野・林, 2008), 本 研究では市販の統計ソフト JMP13.2.1 (SAS Institute Inc., Cary, NC) を用いたので，このソフトでパーティションと 呼んでいる決定木分析の方法に従った。 なお，この方法に よる解析は，いくつかの報告で使われている (Olatinwo et al., 2009; Tanaka et al., 2015; Mehra et al., 2016; Mauro et al.,
2018）.この方法では，対話的な方法で二分木を作成する. 1 分岐ごとに分岐基準となる統計量として $G^{2}$ (尤度比の力 12 乗值) と対数価值の 2 つが出力され，デフォルトでは 対数価值が優先され分岐される. 対数価值は, $-\log 10(p$ 值) で定義される統計量である. 式の中の $p$ 值は，水準数 の多い説明変数が採用されやすい傾向を是正した $p$ 值であ る (JMP 13.2 マニュアル https://www.jmp.com/ja_jp/support/ jmp-software-updates/jmp13-manual-pdf.html)。 モデルの作成 は，分岐先に含まれる固場数が 10 未満になるまで続けた。

生産者围場の調查では，いくつかの説明変数を把握でき ず，欠測值を含むデータとなることが多かった。そのため 解析では欠測值をカテゴリとして扱うオプションを用い た．この場合，欠測は 1 つのカテゴリとして扱われ，対数 価值を基準に分岐のいずれか一方にまとめて振り分けられ た (JMP 13.2 マニュアル).

\section{6. 決定木モデルの検証}

モデルの検証には，農研機構北陸研究拠点 (上越市) にある戋場の調查データと既報 (石本・岩田, 2018) に ある戋場データを用いた（Table 2)。前者は 17 围場あり (2014 2018 年調查), この内 1 固場は引用データ (北信越

Table 2. Field data for testing of the tree model

\begin{tabular}{|c|c|c|c|c|c|c|c|c|c|c|}
\hline No. ${ }^{a}$ & Year & $\begin{array}{l}\text { Name of } \\
\text { field }\end{array}$ & $\begin{array}{c}\text { Area } \\
\text { (a) }\end{array}$ & Cultivar & $\begin{array}{l}\text { Name of } \\
\text { soybean } \\
\text { cropping } \\
\text { years }\end{array}$ & $\begin{array}{l}\text { Damage } \\
\text { rate in the } \\
\text { previous year } \\
(\%)\end{array}$ & $\begin{array}{c}\text { Distance to } \\
\text { the nearest } \\
\text { source field } \\
(\mathrm{m})^{\mathrm{b}}\end{array}$ & $\begin{array}{l}\text { No. of } \\
\text { terminal nodes } \\
\text { classified by } \\
\text { tree model }\end{array}$ & $\begin{array}{c}\text { Damage } \\
\text { rate } \\
(\%)\end{array}$ & $\begin{array}{c}\text { Damage } \\
\text { level }^{\mathrm{c}}\end{array}$ \\
\hline 1 & 2014 & $\mathrm{~g}$ & 4.8 & Enrei & 11 & 28.1 & 0 & 4 & $28.8^{\mathrm{d}}$ & High \\
\hline 2 & 2015 & $\mathrm{a}$ & 9.0 & Enrei & 5 & 48.7 & 0 & 4 & 45.3 & High \\
\hline 3 & 2015 & d & 7.1 & Enrei & 1 & - & 6 & 2 & 10.3 & Moderate \\
\hline 4 & 2016 & $\mathrm{e}$ & 7.1 & Enrei & 1 & - & 5 & 2 & 35.8 & High \\
\hline 5 & 2016 & $\mathrm{~d}$ & 7.1 & Enrei & 2 & 10.3 & 0 & 3 & 34.2 & High \\
\hline 6 & 2016 & c-east & 3.5 & Enrei & 3 & 29.4 & 0 & 4 & 57.6 & High \\
\hline 7 & 2016 & c-west & 3.5 & Enrei & 3 & 29.4 & 0 & 4 & 80.7 & High \\
\hline 8 & 2016 & $\mathrm{a}$ & 9.0 & Enrei & 6 & 45.3 & 0 & 4 & 74.8 & High \\
\hline 9 & 2017 & $\mathrm{e}$ & 7.1 & Enrei & 2 & 35.8 & 0 & 4 & 54.1 & High \\
\hline 10 & 2017 & $d$ & 7.1 & Enrei & 3 & 34.2 & 0 & 4 & 31.8 & High \\
\hline 11 & 2017 & $\mathrm{~b}$ & 7.8 & Enrei & 1 & - & 20 & 2 & 5.1 & Moderate \\
\hline 12 & 2017 & $\mathrm{a}$ & 9.0 & Enrei & 7 & 74.8 & 0 & 4 & 38.9 & High \\
\hline 13 & 2018 & $\mathrm{f}$ & 7.1 & Satonohohoemi & 1 & - & 5 & 2 & 1.4 & Low \\
\hline 14 & 2018 & $\mathrm{e}$ & 7.1 & Enrei & 3 & 54.1 & 0 & 4 & 13.8 & Moderate \\
\hline 15 & 2018 & $\mathrm{c}$ & 7.1 & Satonohohoemi & 1 & - & 5 & 2 & 0.9 & Low \\
\hline 16 & 2018 & $\mathrm{~b}$ & 7.8 & Enrei & 2 & 5.1 & 0 & 3 & 8.8 & Moderate \\
\hline 17 & 2018 & $\mathrm{a}$ & 9.0 & Enrei & 8 & 38.9 & 0 & 4 & 1.4 & Low \\
\hline $18-36^{\mathrm{e}}$ & - & - & - & - & - & - & - & - & - & - \\
\hline
\end{tabular}

${ }^{\text {a }}$ Data for fields No. 1-17 were obtained from research data for NARO experimental fields in Joetsu city. Soybeans were sown at the end of May or early June in each year.

${ }^{\mathrm{b}}$ Source field means fields where soybeans were cropped in the previous year and rice was not cropped in the present year.

${ }^{c}$ Three damage levels: low, moderate and high damage indicate $<5 \%, \geq 5 \%$ and $<15 \%$, and $\geq 15 \%$, respectively.

d The damage rate was taken from data provided by the Research Consortium for crop rotation systems in the Hokushin'etsu region (2016).

${ }^{\mathrm{e}}$ Data for Nos. 18-36 were taken from Ishimoto and Iwata (2018). In their report, the fields $(n=19)$ were named Field J in 2011, Fields A, B, C, D, E, J in 2012, Fields B, D, E, F, I in 2013 and Fields B, D, E, F, H, I, J in 2014. 
水田輪作コンソーシアム，2016）を含む. いずれも生産者 圃場ではないが地域の一般的な栽培方法に従って栽培され ている. また，種子处理剤以外の殺虫剤の施用はない，後 者（石本・岩田，2018）は 19 戋場（2011２014 年調査）あ り，いずれも生産者围場かつ 0 回防除围場である.

決定木で上述の検証用データを分類した後，それぞれの 区分で被害程度低，中，高の围場の数を整理した。次に， 決定木でモデル作成用データも同様に分類して整理した。 そして，各区分の被害程度を 2 群間（モデル作成用データ と検証用データ) で比較した。被害程度低の割合は中，高 の割合より経済的に重要な指標とみなし，2 群間でこの割 合の差の有無を検定した $(2 \times 2$ の分割表を作成して $5 \%$ 有 意水準で Fisher's Exact Test を実施).

\section{7. 各区分で実施された防除回数ごとの被害程度}

1 回防除と 2 回防除の効果を評価するために, 決定木で 1 回または 2 回防除围場データを分類した後, 0 回防除围 場データの分類結果と合わせ，区分ごとに防除回数（０～ 2 回）間で被害程度（低，中，高）を比較した。被害程度低 の割合が $90 \%$ を越える防除回数を，防除効果が安定して
いるとみなし，その区分の戋場に適した防除回数とした.<smiles>[116H]</smiles>

\section{1. 決定木モデルのあてはめ}

最初の分岐において，各説明変数の対数価值の值を比較 したところ，ダイズ連作年数，前年ダイズ戋場までの直線 距離，前年被害粒率の順に值が大きかった（Table 3)。こ の順序は $G^{2}$ でも同様であった。 ダイズ連作年数による分 岐が採用され，作付け初年 (16 固場) と連作 (40 固場) の 2 つに分けられた（Fig. 1)。作付け初年の戋場には，被害 程度低，中，高の順に $11,5,0$ 戋場が含まれた。連作の戋 場には，同じ順に $0,18,22$ 戋場が含まれた。

二番目の分岐は，連作の 40 圃場に対して実施された。 前年被害粒率，ダイズ作付年数，調査年の順に対数価值の 值が大きかった (Table 3)。この順序は $G^{2}$ でも同様であっ た。前年被害粒率による分岐が採用され，被害粒率 $10.8 \%$ 未満（21 固場）と同 10.8\% 以上 (28 固場) の 2 つに分けら れた (Fig. 1)。前年被害粒率の值が欠測であった戋場は後 者の区分に含まれた。な打，前年被害粒率 $10.8 \%$ 未満の

Table 3. Values of the splitting criteria $G^{2}$ (likelihood-ratio chi-square) and the LogWorth statistic for the three split points

\begin{tabular}{|c|c|c|c|c|c|c|c|}
\hline \multirow{2}{*}{ No. } & \multirow{2}{*}{ Variable } & \multicolumn{2}{|c|}{ First split } & \multicolumn{2}{|c|}{ Second split } & \multicolumn{2}{|c|}{ Third split } \\
\hline & & $G^{2}$ & LogWorth & $G^{2}$ & LogWorth & $G^{2}$ & LogWorth \\
\hline 1 & Year & 12.7 & 2.0 & 8.9 & 1.2 & $\underline{9.3}$ & 1.3 \\
\hline 2 & Prefecture & 6.8 & 1.5 & 0.5 & 0.1 & 6.0 & 1.3 \\
\hline 3 & Local area & 23.0 & 3.5 & 0.5 & 0.0 & $\underline{9.3}$ & 0.8 \\
\hline 4 & Field area & 10.1 & 1.2 & 6.6 & 1.1 & 4.0 & 0.6 \\
\hline 5 & Cultivar & 13.4 & 1.9 & 6.6 & 1.0 & $\underline{9.3}$ & 1.3 \\
\hline 6 & Sowing date & 9.8 & 0.9 & 0.8 & 0.0 & 7.5 & 0.7 \\
\hline 7 & Number of soybean cropping years & $\underline{42.9}$ & $\underline{9.6}$ & 9.8 & 1.7 & 0.0 & 0.0 \\
\hline 8 & Damage rate in the previous year & 30.5 & 6.2 & $\underline{16.7}$ & $\underline{3.4}$ & 0.0 & 0.0 \\
\hline 9 & Distance to the nearest source field & 33.9 & 7.6 & $\overline{0.0}$ & $\overline{0.0}$ & 7.5 & 1.4 \\
\hline
\end{tabular}

Underlined numerical values represent the largest value in each split point.

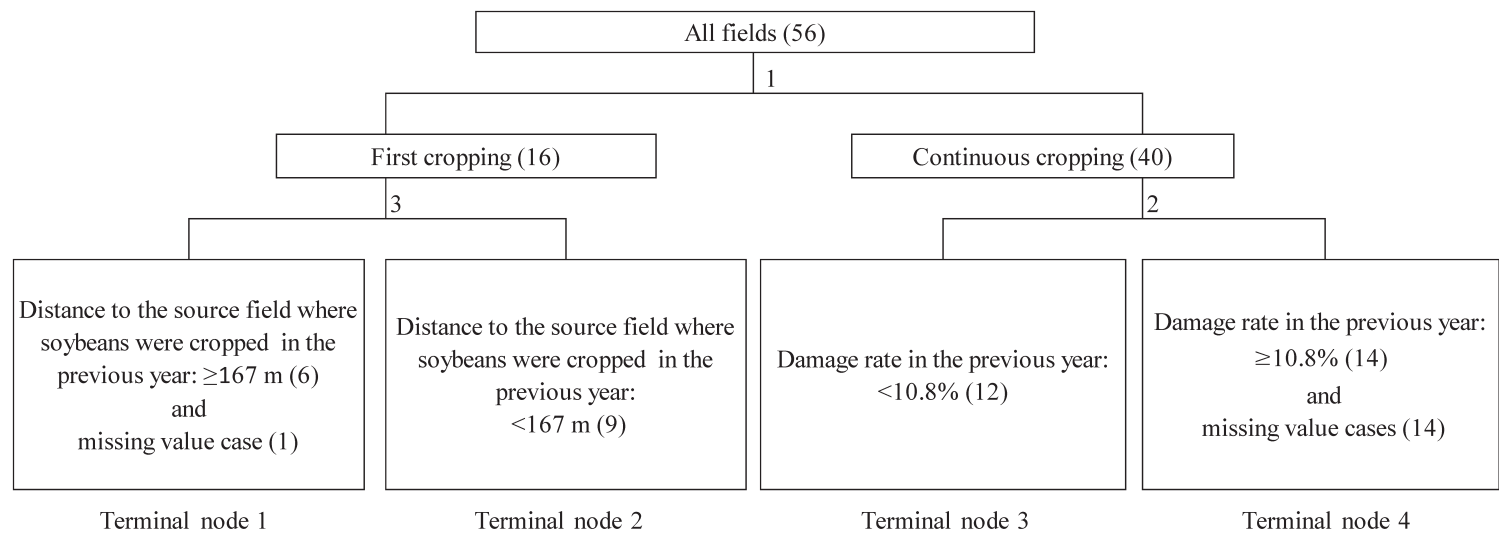

Fig. 1. Results of fitting a decision tree model to data for uncontrolled fields (no insecticide treatment after August 21). The numerical values in parentheses are the number of fields. The numerical values 1-3 near the split points indicate the first, second, and third split points 
圃場には，被害程度低，中，高，欠測の順に $0,11,1,0$ 固場が含まれた。同 $10.8 \%$ 以上の固場には，同じ順に 0,4 , 10，14 固場が含まれた (Fig. 1).

三番目の分岐は，初作の 16 固場に対して実施された. 前年ダイズ击場までの直線距離の対数価值は，他の变数の 值よりやや大きく, 次いで調査年, 県名, 品種の值が大き かった (Table 3)。この順序は $G^{2}$ では異なり, 調査年, 県 名, 品種の值が大きく, 次いで直線距離, 播種日であった. 対数価值を優先すると，前年ダイズ固場までの直線距離が 採用され，直線距離 $167 \mathrm{~m}$ 未満 (9 圃場) と $167 \mathrm{~m}$ 以上 (7 圃場）の 2 つにデータは分けられた。前作ダイズ戋場まで の距離が欠測だった固場は後者の区分に含まれた。なお， モデル作成に使用したデータでは，距離のデータ点は少な く, $100 \mathrm{~m}$ 以上の水準も $121,167,200 \mathrm{~m}$ のみで粗かった. また, 直線距離 $167 \mathrm{~m}$ 未満の固場には, 被害程度低, 中, 高，欠測の順に 4, 5, 0,0 嘈場が含まれた. 同 $167 \mathrm{~m}$ 以上 の戋場には，同じ順に 6, 0,0,1 固場が含まれた（Fig. 1).

分岐後の葉に含まれるデータ数が 10 を下回ったので 3 回の分岐で解析を止めた４つの葉に分岐するモデルが 作成された（Fig. 1)。各葉の被害程度を相対的に低いほ うから高いほうへ並べ番号をつけると，区分1（初作，直 線距離 $\geqq 167 \mathrm{~m}$ ), 区分 2 (初作, 直線距離 $<167 \mathrm{~m}$ ), 区 分 3 (連作，前年被害 $<10.8 \%$ ), 区分 4 (連作，前年被害 $\geqq 10.8 \%$ ）となった (Fig. 1).

\section{2. 決定木モデルの検証}

作成した決定木で検証用データを分類したところ，区分 1 の嘈場はなかったが，区分 2,3，4 には順に 10, 16, 10 固 場が含まれた（Table 4).

区分 2 の被害程度低, 中, 高の圃場の割合は, 検証用デー タでは順に $70,20,10 \%(n=10)$ であり，モデル作成用デー
タでは順に 44, 66, $0 \%(n=9)$ であった (Table 4). 両デー タ間で被害程度低の圃場の割合に有意な差は認められな かった (Fisher's exact test, $p>0.05$ )。また，被害程度高の 割合は両データとも低かった.

区分3の被害程度低, 中, 高の圃場の割合は，検証用デー タでは順に $56,13,31 \%(n=16)$ であり，モデル作成用デー タでは順に $0,92,8 \%(n=12)$ であった。両データ間で被 害程度低の固場の割合に有意な差が認められた（Fisher's exact test, $p=0.003)$. 区分 3 の被害構成は両データ間で異 なり，被害程度低の割合に違いがあることが分かった。

Table 4. Comparison of the number of fields at each damage level between the modeling and test data for each terminal node $^{\text {a }}$

\begin{tabular}{|c|c|c|c|c|c|c|c|c|}
\hline \multirow{2}{*}{$\begin{array}{c}\text { No. of } \\
\text { terminal } \\
\text { nodes }\end{array}$} & \multirow{2}{*}{$\begin{array}{l}\text { Data } \\
\text { type }\end{array}$} & \multirow{2}{*}{$n$} & \multicolumn{6}{|c|}{$\begin{array}{l}\text { Number of fields at each of } \\
\text { the three damage levels }(\%)\end{array}$} \\
\hline & & & \multicolumn{3}{|c|}{ Low $^{b}$} & \multicolumn{2}{|c|}{ Moderate } & High \\
\hline \multirow[t]{2}{*}{1} & Modeling & 6 & 6 & $(100)$ & & 0 & $(0)$ & (0) \\
\hline & $\mathrm{Test}^{\mathrm{c}}$ & 0 & - & - & & - & - & - \\
\hline \multirow[t]{2}{*}{2} & Modeling & 9 & 4 & (44) & \multirow{2}{*}{ n.s. } & 5 & (66) & (0) \\
\hline & Test & 10 & 7 & (70) & & 2 & (20) & $1 \quad(10)$ \\
\hline & Modeling & 12 & 0 & $(0)$ & & 11 & (92) & (8) \\
\hline & Test & 16 & 9 & $(56)$ & & 2 & (13) & $5 \quad(31)$ \\
\hline & Modeling & 14 & 0 & $(0)$ & \multirow{2}{*}{ n.s. } & 4 & (29) & $10 \quad(71)$ \\
\hline & Test & 10 & 1 & (10) & & 1 & (10) & $8 \quad(80)$ \\
\hline
\end{tabular}

a Modeling data were obtained from a survey of farmers' fields from 2015 to 2018. Test data were obtained from research data for NARO experimental fields or taken from Ishimoto and Iwata (2018).

b Asterisks $\left({ }^{*}\right)$ indicate a significant difference in the ratio of lowdamage-level fields between the modeling and test data. Not significant (n.s.) indicates no significant difference in the ratio. Fisher's exact test was conducted at the $5 \%$ significance level.

${ }^{c}$ No field was classified into terminal node 1 in the test data.

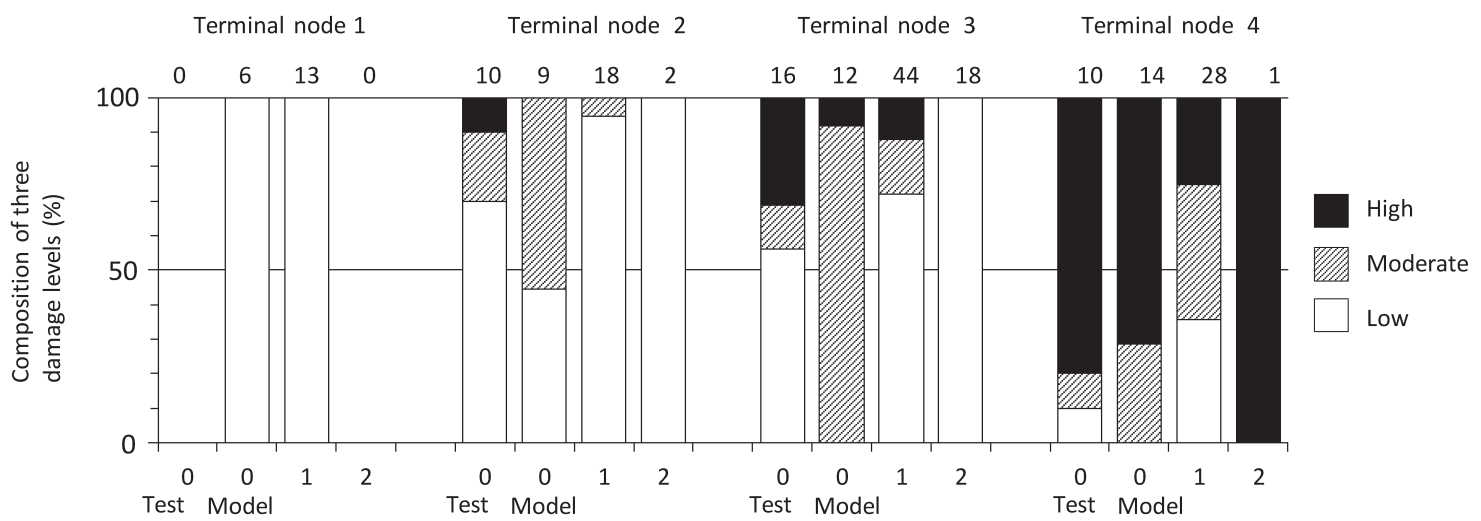

Number of insecticide treatments

Fig. 2. Composition of the three damage levels for each number of insecticide treatments in each terminal node. The numerical values above the bar indicate the number of fields in each treatment. The number of insecticide treatments indicates the number of treatments after August 21 in each growing season. The three damage levels are low (damage rate $<5 \%)$, moderate $(\geq 5 \%$ and $<15 \%)$, and high $(\geq 15 \%)$. Model 0 means data for modeling of the tree model and Test 0 means data for testing, which were obtained from other uncontrolled fields as shown in Table 2. 
区分4の被害程度低，中，高の圈場の割合は，検証用デー タでは順に $10,10,80 \%(n=10)$ であり, モデル作成用デー タでは順に $0,29,71 \%(n=14)$ であった。両データ間で被 害程度低の割合に有意な差は認められなかった (Fisher's exact test, $p>0.05)$ 。また，被害程度高の割合はいずれも 高かった.

検証用データを決定木で分類し区分単位で見た場合，区 分番号が大きいほど被害程度は高かった (区分 2,3,4の順) (Fig. 2). 各区分の被害程度の相対的な順序は，モデル作 成用データと検証用データとの間に違いがなかった.

\section{3. 各区分の圃場で実施された防除回数ごとの被害程度}

区分 1 に打ける被害程度低の粗場の割合は, 0 回防除, 1 回防除いずれも $100 \%$ であり，防除回数によらずこの割 合は基準として設定した 90\% を越える高い值だった（Fig. 2). 区分 1 の 2 回防除には分類された戋場がなかった. 区分 2 に打ける被害程度低の割合は，0，1，2 回防除の順 に 44, 94, 100\%であり, 1 回以上防除があるとこの割合は $90 \%$ を越えた。句分 3 に打ける被害程度低の割合は，0，1， 2 回防除の順に $0,69,100 \%$ であり, 防除が 2 回あるとこ の割合は $90 \%$ を越えた。 区分 4 に打ける被害程度低の割 合は，0, 1 回防除の順に $0,36 \%$ であった. 2 回防除は被害 程度高の 1 圃場のみであった。 区分 4 では，被害程度低の 割合が $90 \%$ を越える防除回数はなかった.

\section{考察}

生産者圃場調查で得られた 0 回防除圃場のデータに決定 木モデルをあてはめたところ, 3 つの説明変数（ダイズ連作 年数，前年被害粒率，前年ダイズ戋場までの直線距離）に よって，畨場を 4 つに分類する決定木が作られた（Fig. 1).

決定木の最初の分岐では，ダイズ連作年数でデータが二 分された．これまでも連作すると被害が大きくなることは 知られ，輪作が基本的な防除対策として推奨されている (船迫ら, 1977; 小野ら, 2011; 石本・岩田, 2018)。連作戋 場では，前年にダイズ萊内で子実を食害しながら成長し た幼虫が，莢の下の土壌中に移動して土荋を作り越冬し， 8 月ごろ蛹化羽化する (樋口・望月, 2011). 従って, 初作 と連作との間には，固場内から成虫が羽化するか否かとい う違いがあると考えられることから（石本・岩田，2018）, モデルが全戋場を初作圃場と連作圃場に分割したことは妥 当と考えられた。

2つ目の分岐では，連作圃場データが前年の被害粒率で 二分された．これまでの研究で，前年発生した幼虫数が翌 年の成虫数に影響する可能性があると考えられている (平 井，1986）。また，年次間差が認められるものの，前年の 被害粒率と当年のフェロモントラップ誘殺数との間には関 連が認められ，さらに，当年のフェロモントラップ誘殺数 と被害粒率との間にも関連が認められることが報告されて
いる(石本・岩田, 2018)。これらの知見から，モデルが 連作戋場を前年被害粒率が低い戋場と高い戋場に分割した のは妥当と考えられた。

3つ目の分岐では，発生源である前年のダイズ戋場まで の直線距離で初作圃場データが二分された (Fig. 1)。この 分岐で用いた初作戋場のデータ数は少なく, 説明変数間の 分岐基準值の差も小さかった（Table 3)。しかし，本種成 虫の移動性は低いとされ，ダイズ以外の寄主植物としてッ ルマメ Glycine soja Siebold \& Zucc. とクズ Pueraria lobata (Willd.) Ohwi の 2 種があるものの利用は少ないとされて いる（梶原ら，1986；樋口・望月，2011）。これらのことか ら，本種に打いては発生源となるダイズ作付け戋場から離 れるほど移入する可能性は低くなると考えられ，モデルが 初作圃場を発生源から遠い固場と近い圃場に分けたのは妥 当と考えられた。

決定木モデルの作成では圃場が 4 つに分類されたが，こ れらを区分単位で被害程度が低い順に並べ番号をつける と, 区分 1 (初作, 直線距離 $\geqq 167 \mathrm{~m}$ ), 区分 2 (初作, 直 線距離 $<167 \mathrm{~m}$ )，区分 3 (連作，前年被害 $<10.8 \%$ )，区分 4 （連作，前年被害 $\geqq 10.8 \%$ ）となった（Fig. 2)。一方，検 証用データを決定木で分け，同様に区分単位で被害程度が 低い順に並べると，各区分（区分 2４）はその区分番号通 りの順序で並んだ (Fig. 2)。 また，区分 2，4に打いては， 検証用データとモデル作成用データとの間で被害程度低の 割合に違いは認められず，被害構成も似ていた（Table 4). 上述したように，本種についてのこれまでの知見は，3つ の分岐の順序や選択された説明変数を支持していた。 これ らから，区分番号は被害発生リスクの順序を表すと考えら れた。また，4区分の順序によるリスク推定は今回の調査 地域以外にも広く適用できる可能性があると考えられた。

決定木のリスク区分の被害構成が安定している場合に は，その区分に一定の防除対策を対応させることができる と考えられる. 本研究の区分 2,4 に打いては, 被害構成が 検証用データとモデル作成用データとの間で大きな違いは なかった（Table 4)。区分 2 には被害程度低の畨場が 44 ま たは $70 \%$ 含まれ，区分 4 には，被害程度高の圃場が 71 ま たは $80 \%$ 含まれていた (Table 4). 従って，区分 2 に被害 程度低のみ，区分 4 に被害程度高のみが分類されるような ことはないものの，これらの区分では被害構成が安定して いると考えられた。また，区分 2 では 1 回防除以上で被害 程度低の割合は $90 \%$ を越えた（Fig. 2)。区分 4 では，被 害程度低の割合が $90 \%$ を越える防除回数はなかった。こ れらから，作付け前の時点における適当な防除対策は，区 分 2 では 1 回防除, 区分 4 では水稲との輪作と考えられた.

区分 1 は, 0 回と 1 回防除のいずれでも被害程度低の戋 場が 100\% で防除の有無によらず被害は少なかった（Fig. 2). 区分 1 に分類されるのは，初作で発生源から遠い圃 
場であることから，4つの区分の中で最も被害発生リスク が低いと考えられる.ただし，区分 1 については別データ による沉用性の検証はできなかった，また，説明変数であ る連作围場までの直線距離のデータ点が粗く, 区分 2 と の境界值 $167 \mathrm{~m}$ の精度は高くないと考えられた。これらか ら，作付け前の時点に打ける区分 1 の防除対策は, 0 回防 除または区分 2 の対策と同等の 1 回防除と考えられた。な お，本種について標識再捕試験をした報告では，被害の過 小推定を避ける保守的な前提を発生源密度などにおいた 上で，移入虫による被害がほぼなくなる隔離距離を $352 \mathrm{~m}$ と推定している (Takeuchi et al., 2019). 発生源からの距離 が，この距離より大きければ作付け前の時点で 0 回防除を 選択できる可能性は高いと考えられる.

区分 3 では検証用データとモデル作成用データとの間 で，被害程度の構成は異なり，前者では被害程度低の割 合が高かった（Fig. 2)。一方，この区分に分類された生産 者圃場では, 2 回防除で被害程度低の割合は $90 \%$ を越えた (Fig. 2)。これらから，区分 3 では 2 回防除の効果は高い ものの，分類される围場の被害構成が不安定なため，対策 の絞り込みは難しいと考えられた。作付け前の時点におけ る区分 3 に適当な防除対策の候補は, 2 回防除に加え，区 分 4 と同じ水稲との輪作，区分 2 と同じ 1 回防除が挙げら れると考えられた。な打，これまで本種に対する薬戍防 除試験では，防除適期が薬剤によって異なることや（久保 田・横田, 2015), 多発生条件でも 1 回防除が十分な効果 を示した事例 (木村·石谷, 2009; 久保田・横田, 2015; 福 田・奥谷, 2018）が報告されている. 区分 3 に打ける防除 回数や防除刻の選択方法については，さらに検討が必要と 考えられる。

本研究では数多くの生産者戋場の調査をして, 作付け前 に被害リスクの推定と対策の選定をする方法を作成した。 これまで，有効な農薬の散布や水稲との輪作が本種の防除 対策として推奨されているが（梶原ら，1986），それらを 被害発生リスクに基づいて合理的に選択する方法はなかっ た．生産者圃場の実態調査で蓄積したデータを用い，対 策の選択法を表すチャートを直接作成するアプローチは, 労力や時間がかかるものの研究結果の生産者围場への適 用や生産者への提示が比較的容易と考えられる。 ただし， チャートによる作付け前の推定は，対策の大きな方向付け をするためのものである. 推定から防除適期までの期間が 長いため, 気象条件等によって選択した対策が不適になる 可能性も高い。防除適期までの期間に発生予察情報など新 しい情報を収集して，作付け前以外の多様な時点で対策を 検討することも重要と考えられる.

$$
\text { 摘要 }
$$

ダイズ害虫マメシンクイガを対象に，作付け前の時点で
被害リスクを推定して防除対策を選択する方法を構築する ために, 2015〜2018 年に新潟県，長野県の 200 以上の生産 者围場を調査した。これらの戋場では，本種に対する防除 回数は $0 \sim 2$ 回であった. 0 回防除戋場データを用いて決 定木分析をしたところ, 3 つの説明変数 (ダイズ連作年数, 前年被害粒率，前年ダイズ戋場までの直線距離）によって 圃場を 4 つの区分に分類する決定木が作られた４つの 区分は，含まれる戋場の被害程度が小さい順に区分番号 (区分 1〜4）をつけることができた。この区分番号の順序 は別の 0 回防除围場データ (検証用データ) でも違いはな かった。 1 回または 2 回防除された生産者围場を決定木で 分類し，区分ごと，防除回数ごとに被害程度を比較したと ころ，最も被害が大きい区分 4 以外では，防除回数が増え るにつれて被害程度低の圃場の割合は上昇し $90 \%$ を越え た。これらの結果から，作成した決定木の区分番号は，各 区分の被害発生リスクの順序を示すと考えられた。また， 作付け前の被害リスク推定に基づいて防除回数や輪作など の対策を合理的に選択することができると考えられた.

\section{引用 文 献}

Dent, D. (2000) Insect Pest Management. 2nd ed. CABI Publishing, New York. 410 pp.

Dumbauld, B. R., S. Booth, D. Cheney, A. Suhrbier and H. Beltran (2006) An integrated pest management program for burrowing shrimp control in oyster aquaculture. Aquaculture 261: 976-992.

福田侑記 · 奥谷恭代 (2018) 鳥取県におけるマメシンクイガの 発生消長とジアミド系殺虫剤の防除効果. 植物防疫 72: 319322. [Fukuda, Y. and Y. Okutani-Akamatsu (2018) Seasonal prevalence of soybean pod borer Leguminivora glycinivorella in Tottori prefecture and effect of diamide insecticides. Plant Prot. 72:319-322.]

船迫勝男 - 伊藤春男 - 小林 尚 - 奥 俊夫 (1977) 宮城県に おけるダイズ子実害虫相の地域性ならびに虫害粒率の発生 予察。北日本病虫研報 28：17-21. [Funabasama, K., H. Ito, T. Kobayashi and T. Oku (1977) Local variation and prediction of insect injuries to soybean seeds in Miyagi prefecture. Ann. Rept. Plant Prot. North Japan 28: 17-21.]

樋口博也・望月文昭 (2011) マメシンクイガのダイズ固場 での発生生態. 植物防疫 65:225-227. [Higuchi, H. and F. Mochizuki (2011) Ecology of soybean pod borer, Leguminivora glycinivorella (Matsumura) (Lepidoptera: Tortricidae) in soybean fields. Plant Prot. 65: 225-227.]

平井一男 (1986) マメシンクイガの被害粒率と気温打よび降 水量の関係. 応動昆 30：196-199. [Hirai, K. (1986) The relationship of air temperature and precipitation to percent damaged beans by the soybean podborer, Leguminivora glycinivorella Matsumura (Lepidoptera: Tortricidae). Jpn. J. Appl. Entomol. Zool. 30: 196-199.]

廣野元久・林 俊克 (2008) JMP による多変量データ活用術 2 訂版. 海文堂出版, 東京. 331 pp. [Hirono, M. and T. Hayashi (2008) Method to Utilize Multivariate Data by JMP. 2nd ed. 
Kaibundo, Tokyo. 331 pp.]

北信越水田輪作コンソーシアム（2016）「北信越地域に打ける高 性能機械の汎用利用と機械化一貫体系を基軸とした低コス 卜・高収益水田輪作の実証」技術成果の紹介. 農研機構中 央農研北陸研究センター, 上越. 34 pp. [Research Consortium for crop rotation systems in the Hokushin'etsu region (2016) Introduction of the Technical Achievements of the Research Project, Demonstration of a Low-cost and High-yield Crop Rotation System in the Hokushin'etsu Region Based on General-purpose Use of the Latest Machinery and the Mechanization of All Cultivation Processes. NARO Hokuriku Research Center, Joetsu. 34 pp.]

石本万寿広・岩田大介 (2018) マメシンクイガ（チョウ目：八 マキガ科) の発生量に及ぼすダイズ連作の影響. 応動昆 62: 239-247. [Ishimoto, M. and D. Iwata (2018) Effects of the continuous cropping of soybean plants on the occurrence of soybean pod borer, Leguminivora glycinivorella (Lepidoptera: Tortricidae). Jpn. J. Appl. Entomol. Zool. 62: 239-247.]

伊藤健二 · 水谷信夫 ·田㴊 研 · 守屋成一 (2006) カメムシ低 密度地域のダイズ生産における適切な農薬散布回数. 関東 病虫研報 53:105-110. [Ito, K., N. Mizutani, K. Tabuchi and S. Moriya (2006) Determination of the optimal number of pesticide spray applications in soybean cultivation in a low density stinkbug area. Ann. Rept. Kanto Pl. Prot. Soc. 53: 105-110.]

梶原敏宏・梅谷献二・浅川 勝 (編) (1986) 作物病害虫ハンド ブック. 養賢堂, 東京. 1446 pp. [Kajiwara, T., K. Umeya and M. Asagawa (eds.) (1986) Handbook of Crop Pests. Yokendo, Tokyo. 1446 pp.]

加進丈二 · 狐塚慶子 - 辻 英明 - 畑中 篤 ·阿部倫則 - 安藤慎一 朗・町 直樹・佐伯研一 (2010) ダイズほ場に打けるフェ ロモントラップを用いたマメシンクイガの発生調査. 北日 本病虫研報 61：133-136. [Kashin, J., K. Kitsunezuka, H. Tsuji, A. Hatanaka, T. Abe, S. Ando, N. Machi and K. Saeki (2010) Monitoring of soybean pod borer Leguminivora glycinivorella (Lepidoptera: Tortricidae) using pheromone trap in soybean fields. Ann. Rept. Plant Prot. North Japan 61: 133-136.]

木村勇司・石谷正博 (2009) 合成ピレスロイド剤によるマメ シンクイガの効率的防除. 北日本病虫研報 60：180-185. [Kimura, Y. and M. Ishitani (2009) Effective control of soybean pod borer Leguminivora glycinivorella using synthetic pyrethroids. Ann. Rept. Plant Prot. North Japan 60：180-185.]

小林 尚・奥 俊夫 (1976) 東北地方におけるダイズ害虫の発 生相, 虫害相ならびに虫害発生量の予察に関する研究. 東 北農試研報 52：49-106. [Kobayashi, T. and T. Oku (1976) Studies on the distribution and abundance of the invertebrate soybean pests in Tohoku district, with special reference to the insect pests infesting the seeds. Bull. Tohoku Natl. Agr. Exp. Stn. 52: 49-106.]

Kobayashi, T. and T. Oku (1980) Sampling lepidopterous pod borers on soybean. In Sampling Methods in Soybean Entomology (M. Kogan and D. C. Herzog, eds.). Springer, New York, pp. 422-437.

久保田真衣・横田 啓 (2015) マメシンクイガに対する各種殺 虫殽の防除適期. 北日本病虫研報 66：129-131. [Kubota, M. and H. Yokota (2015) Optimal timing of application of sev- eral insecticides for control of soybean pod borer, Leguminivora glycinivorella. Ann. Rept. Plant Prot. North Japan 66: 129131.]

Kuwayama, S. (1928) Notes on Laspeyresia glycinivorella Matsumura, the soy bean pod borer. J. Coll. Agric. Hokkaido Imp. Univ. 19: 261-281.

松村松年 (1898) 大豆の害虫に就て. 動物学雑誌 10：126-130. [Matsumura, S. (1898) An injurious insect of soy bean. Zool. Mag. 10: 126-130.]

Mauro, G. D., P. A. Cipriotti, G. Santiago and J. L. Rotundo (2018) Environmental and management variables explain soybean yield gap variability in Central Argentina. Eur. J. Agron. 99: 186-194.

Mehra, L. K., C. Cowger, K. Gross and P. S. Ojiambo (2016) Predicting pre-planting risk of Stagonospora nodorum blotch in winter wheat using machine learning models. Front. Plant Sci. 7: 390.

Mumford, J. D. and G. A. Norton (1984) Economics of decision making in pest management. Annu. Rev. Entomol. 29: 157-174.

内藤 篤・正木十二郎 (1962) シロイチモジマダラメイガ及び マメシンクイガの分布に関する研究. 農事試験場研究報告 2: 145-228. [Naito, A. and J. Masaki (1962) Studies on the distribution and abundance of the lima bean pod borer, Etiella zinckenella Tretischke, and the soy bean pod borer, Grapholitha glycinivorella Matsumura. J. Central Agric. Exp. Stn. 2: 145-228.]

中筋房夫 (2008) 総合的害虫管理学の確立に向けて. 岡山大学農 学部学術報告 97: 83-86. [Nakasuji, F. (2008) Establishment of science for integrated pest management. Sci. Rep. Fac. Agric. Okayama Univ. 97: 83-86.]

奥 俊夫 (1993) 昆虫の移動性と害虫管理. 北日本病虫研報 44: 1-5. [Oku, T. (1993) Migratory activity of insects and pest management. Rept. Plant Prot. North Japan 44: 1-5.]

Olatinwo, R. O., J. O. Paz, S. L. Brown, R. C. Kemerait, A. K. Culbreath and G. Hoogenboom (2009) Impact of early spring weather factors on the risk of tomato spotted wilt in peanut. Pl. Dis. 93: 783-788.

小野 亨 (2009) 宮城県北部における最近のダイズ害虫被害の 発生と特徵. 北日本病虫研報 60：186-188. [Ono, T. (2009) Recent occurrence of soybean seed insect pests in northern area of Miyagi prefecture. Ann. Rept. Plant Prot. North Japan 60: 186-188.]

小野 亨·笹原剛志 · 城所 隆 - 加進丈二 · 辻 英明 - 星 信幸 （2011）宮城県のダイズ主要病害虫の IPM 体系に関する研 究 1. 近年の病害虫発生の特徴と防除対策. 宮城古川農試報 9: 35-53. [Ono, T., M. Sasahara, T. Kidokoro, J. Kashin, H. Tsuji and N. Hoshi (2011) Studies of integrated pest management system of the major insect pests and diseases of soybean in Miyagi prefecture 1. Recent occurrence and control of soybean insect pests. Bull. Miyagi Pref. Furukawa Agric. Exp. Stn. 9: 35-53.]

小野寺鶴将 (2012) 大豆のマメシンクイガに対する防除適期の 判断手法と被害軽減対策. 農家の友 64：92-94. [Onodera, K. (2012) Optimal control timing and control method to decrease damage caused by the soybean pod borer. Noukanotomo 64: 92-94.]

Tabata, J., T. Yokosuka, M. Hattori, M. Ohashi, H. Noguchi and H. Sugie 
(2008) Sex attractant pheromone of the limabean pod borer, Etiella zinckenella (Treitschke) (Lepidoptera: Pyralidae), in Japan. Appl. Entomol. Zool. 43: 351-358.

高橋良知・菊池英樹・中村智幸 (2011) 秋田県のダイズにおけ るウコンノメイガの要防除水準の設定. 北日本病虫研報 62 : 130-133. [Takahashi, Y., H. Kikuchi and T. Nakamura (2011) Control threshold of bean webworm, Pleuroptya ruralis, in soybean fields of Akita prefecture. Ann. Rept. Plant Prot. North Japan 62: 130-133.]

高野俊昭 (1985) 重回帰式によるダイズ主要子実害虫の被害 量の予察. 北日本病虫研報 36：58-59. [Takano, T. (1985) Prediction of major insect pests infecting soybean seeds by the multiple regression equation. Ann. Rept. Plant Prot. North Japan 36: 58-59.]

竹内博昭 (2018) 湛水条件のマメシンクイガ幼虫生存率に及ぼ す温度の影響. 北陸病虫研報 67: 5-14. [Takeuchi, H. (2018)

Effect of flooding temperature on larval survival of the soybean pod borer Leguminivora glycinivorella. Proc. Assoc. Plant Prot. Hokuriku 67: 5-14.]

Takeuchi, H., N. Endo and K. Yamamura (2019) Estimation of dispersal distance of the soybean pod borer Leguminivora glycinivorella
(Lepidoptera: Tortricidae) by mark-recapture experiments. Appl. Entomol. Zool. 54: 285-296.

Tanaka, A., M. Diagne and K. Saito (2015) Causes of yield stagnation in irrigated lowland rice systems in the Senegal River Valley: Application of dichotomous decision tree analysis. Field Crop Res. 176: 99-107.

對馬佑介・木村勇司・藤村建彦 (2017) 青森県のマメシンクイ ガ甚発生戋場における発生消長と無人へリコプター散布によ る防除方法の検討. 北日本病虫研報 68：237-241. [Tsushima, Y., Y. Kimura and T. Fujimura (2017) Seasonal occurrence of soybean pod borer Leguminivora glycinivorella and its chemical control by radio-controlled helicopter in soybean fields in Aomori prefecture, Japan. Ann. Rept. Plant Prot. North Japan 68: 237241.]

Valentine, H. T., C. M. Newton and R. L. Talerico (1976) Compatible systems and decision models for pest management. Environ. Entomol. 5: 891-900.

Woodill, A. J., S. T. Nakamoto, A. M. Kawabata and P. Leung (2017) To spray or not to spray: a decision analysis of coffee berry borer in Hawaii. Insects 8: 116. 